\title{
elyra
}

\section{Internet trouvé: impactos da vida digital em certa poesia brasileira}

\author{
Sérgio Bento \\ Universidade Federal de Uberlândia
}

Resumo: O texto visa a refletir sobre o impacto das tecnologias computacionais e digitais sobre a poesia brasileira recente e contemporânea, não a partir de ciberpoesia ou produções que contemplem escrita automática a partir de softwares, mas no escopo da criação poética dita "tradicional", publicada em livros ou em revistas, ou ainda canções populares. Para tal, serão usados poemas de autores como Eduardo Sterzi, Fabiano Calixto, Marcos Siscar, Leila Míccolis, Angélica Freitas, entre outros. Percebe-se, nessa análise, que os avanços da informática e da internet não apenas transformam a temática de parte desse recorte poético, mas principalmente influem em sua construção estrutural. Assim, tenta-se compreender como esse novo contexto tecnológico introjetou-se enquanto forma. Um dos procedimentos mais recorrentes, e por isso aprofundado, foi o do objet trouvé, apropriação de textos existentes em sites e transpostos ao poema.

Palavras-chave: Poesia contemporânea brasileira; objet trouvé; ready-made

Abstract: This article discusses the impact of computer and digital technologies on recent and contemporary so-called 'traditional' poetry, published in books or magazines, or songs in Brazil (without considering cyber poetry or software-automatic writing). Close readings of poets like Eduardo Sterzi, Fabiano Calixto, Marcos Siscar, Leila Míccolis, Angélica Freitas (and others) will show that digital technology and internet not only transformed the content of part of such works, but also affected their structure. Thus, the article attempts to understand how such technological innovations become embedded into this poetic corpus as form, and how the recurrent procedure of the ready-made is an appropriation of existing texts from websites that are transformed into poems.

Keywords: Contemporary poetry in Brazil; objet trouvé; ready-made 
Em constante transformação a partir de sua relação dialética com a sociedade, é natural que a Literatura reaja e responda a grandes mudanças tecnológicas e comportamentais, especialmente quando houver um impacto direto em seus suportes. Pegue-se como exemplo Mallarmé e seus sentimentos paradoxais ao se deparar com o jornal. Em "Mistério nas Letras", o poeta afirma ser aquele novo tipo de publicação diária uma banalização da leitura, vazia de transcendência, que não "interrompe o curso das preocupações" do leitor. Em "O livro, instrumento espiritual" ${ }^{1}$, esse um de seus mais célebres artigos, o jornal é exaltado em suas inovações gráficas, no modo de colocação das notícias e dos anúncios na página (em perspectiva horizontal e vertical), a dobradura da folha, enfim, uma maneira totalmente nova de se encarar o espaço do papel, o que "aproxima de um rito a composição tipográfica", diferente do livro, "mesmo o formato, ocioso". A partir de tais observações, o poeta construiria a base conceitual para o seu último poema, "Um lance de dados jamais abolirá o acaso", em que a disposição dos sintagmas na folha não segue o modelo ocidental tradicional de linhas e parágrafos ou estrofes, mas atomiza-se a partir de grupos de períodos que povoam o espaço em branco da página. Além disso, Mallarmé explora diferentes tipografias, umas maiores - como "manchetes", outras menores, o que acarreta implicações sintáticas (as menores sendo "subgrupos" das maiores, ou seus "apostos" e complementos nominais) e semânticas (as palavras maiores são naturalmente mais impactantes ao leitor). Como se sabe, esse poema foi uma das bases para as vanguardas europeias do começo do século $X X$, bem como a inspiração maior para as neovanguardas do meio do século, em especial os poetas concretos de São Paulo.

Outro momento marcante das relações entre literatura e tecnologia se dá a partir da década de 60, quando há uma relevante escalada no uso de computadores, em muito catapultada pela corrida espacial na Guerra Fria. São conhecidas e já amplamente estudadas diferentes iniciativas de geração de poemas a partir de hardwares e/ou softwares, como as dos grupos franceses OULIPO e ALAMO, ou as de Waldemar Cordeiro e Erthos Albino de Souza no Brasil. Na mesma época, a questão da informática também adentra a produção poética dita "tradicional", que não é digital nem aleatória, mas que vê elementos do novo mundo computacional introjetando-se em sua forma e em seu conteúdo. É paradigmático, por exemplo, o álbum Gilberto Gil, de 1969, um dos mais marcadamente tropicalistas do 
compositor baiano. Com forte carga devedora ao rock progressivo, à psicodelia e à atualização cultural típicas do movimento, as canções nele inclusas abordam amiúde o universo espacial e os astronautas (registre-se que o homem pisou na lua no mesmo ano do lançamento da obra), como em "Volks-Volkswagen blues", escrita pelo próprio Gil ("My Volks-Volkswagen blues / Ready to carry me away / A long way to reach the moon"); a presença tecnológica no cotidiano, como em "2001", composta por Tom Zé e Rita Lee ("A equação me propõe / Computador me resolve"); e a inevitável comparação entre o homem e a máquina:

\author{
Só eu posso pensar \\ Se Deus existe \\ Só eu \\ Só eu posso chorar (Gil 1969: faixa 1)
}

Estes versos pertencem à canção de Gil de sugestivo nome, "Cérebro Eletrônico", metáfora óbvia do computador que "comanda / manda e desmanda / [...] Mas ele não anda", retrato da reflexão corrente na época acerca dos limites da informática. Na melodia, notam-se sons metalizados, dissonantes, com compassos em crescente aceleração e elementos da letra cantados de maneira caótica e não-linear, claramente aludindo a um universo robótico, metálico (em "Futurível", também escrita por Gil e presente no mesmo álbum, ele afirma: "Seu segundo estágio de humanóide hoje se inicia / [...] Na nova mutação / A felicidade é feita de metal"). O efeito gerado pela combinação dos acordes com as palavras traz certo desconforto de um eu que se apega na mais primordial humanidade para rechaçar o rebaixamento do sujeito diante da tecnologia ("Sou muito vivo e sei / Que a morte é nosso impulso primitivo"), modo de resistir na diferença, naquilo que é inalcançável à inteligência artificial, o "pensar", o "chorar", o "morrer" como atos de reafirmação de um estado humano cada vez mais frágil, porém ainda existente.

Se a influência do mundo da informática é notada, enquanto forma, na harmonia e na melodia da canção popular, na poesia escrita ela é revertida em sátira por José Paulo Paes, com a reversão de fundamentos-chave da computação básica contra si mesma, em clave altamente irônica. Em Meia Palavra, de 1973 - portanto bem próximo ao álbum de 
Gilberto Gil -, o poema "Metassoneto ou o computador irritado" apresenta quatro estrofes ilegíveis, com pseudopalavras formadas apenas pelas letras "a", "b", "c" e "d", referência às sequências binárias que compõem as linguagens de programação. Ao final, uma longa linha com a formação "blablablabla", expressão que remete a um discurso desimportante. Desconstrói-se tanto a poesia gerada por computador como o próprio equipamento.

É curioso notar as reações de Gil e Paes à informatização em uma época prévia ao PC, ou seja, anterior ao contato mais direto do indivíduo com a máquina. As possibilidades computacionais eram, então, uma espécie de abstração, uma promessa de revolução a se dar em breve, e, por isso, amedrontadoras. Sherry Turkle, pesquisadora do MIT que vem se dedicando a propor uma "etnografia digital", identifica, entre as décadas de 60 e 70, uma prevalência desse tipo de reflexão frente ao avanço tecnológico. Diferentemente de outras invenções, o computador não efetua exclusivamente uma função (como o rádio), não é relacionável a algum ente da natureza (como o avião ao pássaro) nem é reduzível a especificações técnicas (como um braço mecânico), mas comporta, em si, uma complexidade que escapa à compreensão daquele que não é programador, ganhando aura de mistério. Sua natureza de plataforma múltipla, capaz de realizar diferentes funções (calcular, organizar, separar, agrupar), só é comparável ao cérebro humano. Por isso, a teórica afirma, em sua obra de sugestivo nome The Second Self: Computers and the Human Spirit - de 1984, portando captando esse momento pré-popularização do computador pessoal - que tal equipamento possui valor "evocatório"2 (Turkle 2005: 19) ao suscitar sentimentos diversos em seus usuários e observadores, análogas, em termos de impacto coletivo, à repercussão dos conceitos psicanalíticos no começo do século XX: “As pessoas têm medo de pensar em si como máquinas, controladas, previsíveis, pré-determinadas, assim como têm medo de pensar em si como "guiadas" por impulsos sexuais ou agressivos" (idem: 272).

O início da interação homem-computador, pois, deu-se de forma bitransitiva: a ideia de semelhança entre o processador e o cérebro tanto gera temor quanto às possibilidades da máquina quanto suscita o questionamento de quem realmente detém o poder, reavivando fantasias de uma "rebelião" das inteligências artificiais tão exploradas pela ficção científica. Essa analogia é o que move a rejeição à tecnologia escancarada nas canções 
citadas de Gilberto Gil e no soneto paródico de José Paulo Paes, ambas as manifestações em claro tom de resistência do indivíduo frente à nova realidade.

Mais de vinte anos depois, já em um contexto de ampla popularização do PC, o próprio Paes retornaria ao tema, em poema publicado no livro póstumo Socráticas, de 2001:

Descartes e o computador

Você pensa que pensa

ou sou eu quem pensa

que você pensa?

Você pensa o que eu penso

ou eu é que penso

o que você pensa?

Bem vamos deixar a questão em suspenso

enquanto você pensa se já pensa

e eu penso se ainda penso (Paes 2008: 478)

No título já se deflagra a atmosfera cômica de um suposto diálogo entre o filósofo francês e a máquina, o que o leva à relativização de sua máxima, cogito ergo sum. A intensa repetição do verbo pensar leva o leitor a uma labiríntica aporia, como que representando o próprio processamento frenético da máquina. Mais uma vez, surge o questionamento de quem está no comando das ações, por meio do quiasmo da segunda estrofe. Finalmente, a oposição "já-ainda" dos últimos versos exibe a simbiose do usuário e de seu processador, unidos cotidianamente em diversas operações pessoais e profissionais. O computador extrapola o que se possa entender por ferramenta ${ }^{3}$ ou equipamento, mas se torna uma extensão virtual do próprio pensamento, em que "locais" de processamento, análise e cálculo vão acontecendo simultânea e irrefletidamente. Isso, somado à substituição do trabalho humano pelo automatismo em tantos ramos de atividade, vai apagando cada vez mais o limite entre indivíduo e máquina, ora complementares, ora intercambiáveis. É nesse sentido que a menção a Descartes traz outra camada significativa ao poema: a imbricação entre pensamento e existência desestabiliza-se de modo definitivo. A hesitação "eu penso se 
ainda penso", no limite, converte-se em "eu penso se ainda existo". As décadas de 90 e 2000 foram paradigmáticas nessa reflexão, que culminou com diversas teorias como o "póshumanismo"4 e o "pós-biológico", que por seu caráter por vezes polêmico, e por se concentrarem sobremaneira na "robotização do corpo" por meio de próteses, chips e outras inovações, não interessam a esta análise.

O fato é que esse texto de Paes simboliza uma percepção do poeta em um momento crucial do processo de informatização do mundo dito "desenvolvido": junto com a proliferação do computador pessoal, vê-se um movimento global de simplificação das interfaces de utilização deste aparelho, mediadas cada vez mais por "máscaras" visuais que elidem as linhas de comando e toda a lógica de programação e as substituem por ícones gráficos que aumentam a sensação de se estar "dentro" da máquina, e não no seu controle. Sherry Turkle, na obra supracitada, chama esse fenômeno de "transparência", no sentido de que a existência de linguagens de software é esquecida pelo operador, que navega em um ambiente dito "amigável", sem nenhuma necessidade de conhecimento técnico. Embora os PCs Macintosh tenham sido pioneiros nessa estrutura, foi o sistema operacional Windows que popularizou de vez a interface visual. Estar ao computador a partir da metade da década de 90 era cada vez menos "como guiar uma máquina e cada vez mais como conversar com alguém" (Turkle 2005: 07), sensação reforçada pelo vocabulário que humanizava o equipamento, como "memória" e "inteligência". "O computador é um novo espelho, a primeira máquina psicológica" (idem: 280), reforça a teórica, o que explica o conflito da voz cartesiana que enuncia o poema, em abalo com seus limites psíquicos e identitários.

É de se compreender que artistas da geração de José Paulo Paes, nascido em 1926, e mesmo Gilberto Gil (de 1942) tenham vivido tais dilemas, que não se encerram na relação ser humano/tecnologia, mas que suscitam outras questões. Um aspecto que chamava a atenção dos novos infonautas era a fragilidade daquele tipo de "memória". A ideia de que uma pane ou um acidente pode fazer desaparecer todo um trabalho intelectual é mais presente, pois não se tem a materialidade de papéis, por exemplo, ou a confiança de durabilidade da própria memória humana. Armando Freitas Filho, poeta de uma geração posterior a Paes, mas ainda formado em uma civilização pré-informática, expressa a relação etérea, delicada e impalpável com a máquina, que passa a ser suporte de escrita e leitura: 


\author{
Você não para de cair \\ fugindo \\ por entre os dedos de todos: \\ água de mina \\ resvalando pelas pedras. \\ Nunca \\ nenhum poema acaba \\ a não ser com um tranco \\ com um corte brusco de luz. \\ As janelas daqui não choram \\ como nos filmes \\ com seu clichê de vidraças \\ feito de chuva e lágrimas \\ que o estúdio e o destino \\ encomendam \\ aos deuses de passagem. \\ De costas é melhor \\ para não perder de vista \\ nem por um segundo \\ nenhum sentido \\ do que estava escrito \\ nem quando, no chão \\ seu corpo \\ a céu aberto! (Freitas Filho 2003: 410)
}

Este é o poema "Na área dos fundos", publicado originalmente em De cor, de 1988, e alusivo ao suicídio de Ana Cristina Cesar, o que é perceptível pela presença da queda e do corpo no chão. Ao mesmo tempo, porém, há um forte tom metalinguístico na reflexão sobre o término do poema e o "sentido / do que estava escrito". Entrelaçam-se as fugacidades da escrita e da vida, ambas fugindo ao controle, escapando pelos dedos. Ao falar certa vez sobre esse texto em uma entrevista, Armando Freitas Filho cita o computador como local de criação poética, e repete a metáfora da água:

A poesia "chega" para mim descontinuadamente. O caderno, a folha casual (mais esta do que aquele), o pedaço de papel (mais este do que aquela) condicionam o que escrevo, forçosamente. Afinal, o 
suporte acaba por influir no que vai "suportando". Como esse pedaço de papel não tem "estatuto" nenhum (se tiver será o de um "volante" passado de mão em mão), o poema se estrutura nesse lugar instável, trêmulo. Quando se fixa através da escrita, primeiro à mão, depois à máquina de escrever mecânica, e, agora (estágio recente), na tela do computador, traz na sua composição essa incerteza. Aliás, com o advento do computador o ciclo da criação, digamos assim, se fecha, pois parece que volto ao começo de tudo, já que escrever nele é como escrever na água do pensamento, quando tudo pode ser, de repente, apagado, reformado, absolvido, sem deixar marcas, apenas o leve incômodo ou remorso de alguma coisa que se perdeu para sempre. (Freitas Filho 2000: 07)

É bom lembrar que a questão da inscrição da letra e a preocupação com a materialidade da literatura são recorrentes na temática desse poeta. Não apenas o papel, receptáculo da palavra, mas também o instrumento responsável por essa gravação, como a caneta, protagonista de um poema em Longa vida: "Deixem-me somente / a pena e os papéis / para as minhas novas ninfas: / a Bic, a Cross [...]", tentativa de se reverter a virtualidade da linguagem em objetos palpáveis, que Ihe dão corpo, forma de reduzir a instabilidade por ele aludida na entrevista acima. Outro estágio é o da máquina de escrever, não à toa o nome da extensa coletânea de suas obras até 2003. Com o computador, a sensação de que jamais se vencerá a intangibilidade poética, agora não mais corporificada em algo táctil, mas tornada dados de um software que roda a partir de um hardware, editável, sob o risco de desaparecer. A água, repetida no poema e em sua resposta ao entrevistador, é a metáfora heraclitiana desse fluxo constante no tempo, em que a inapreensibilidade da poesia e da própria vida reforça o sentimento de perda de algo.

Essa fluidez poética é o que causa a agonia do término do poema, do momento de interrupção da corrente que estanca o pensamento, "tranco" artificial, forçoso, afinal, "nenhum poema acaba", como a água, ele jamais para de jorrar: é interrompido. Tal reflexão remete a um famoso ensaio de Giorgio Agamben, "O fim do poema", em que o filósofo italiano questiona o estatuto do último verso, do encerramento de uma peça poética. Para ele, é o momento em que som e sentido se conciliam, desfazem o descompasso sintáticofônico-semântico causado pelo enjambement, ou seja, é quando a poesia tende à pobreza prosaica, a menos que interrompa tal processo mantendo a tensão entre os dois polos: "No ponto em que o som está prestes a arruinar-se no abismo do sentido, o poema procura uma 
saída suspendendo, por assim dizer, o próprio fim, numa declaração de estado de emergência poética" (Agamben 2002: 146).

Veja-se o poema em questão: a verticalidade da mancha da página, além de delinear a própria queda, exibe cortes bruscos nos versos, mantendo a abertura de sentido que oscila entre o fim da vida e o fim do poema. A leitura é interrompida, ofegante, como se as cesuras dos encavalgamentos tentassem reter o fluxo vital, evitar a perda do controle. $\mathrm{O}$ isolamento de "seu corpo", em meio à oposição chão/céu, marca o cadáver da amiga e o poema pronto (também já um cadáver), ambos no solo - o encerramento da queda -, parados, mas, imediatamente, alçados ao céu aberto do verso seguinte, de onde recomeça o movimento de cair. Dá-se algo próximo à suspensão proposta por Agamben, como o chão se abrisse em firmamento, não sem reter algo, não sem prejuízo à fluidez, ainda que mínima ("nem por um segundo"), para então recomeçar seu processo infinito, em looping, afinal, "Você não para de cair", frase que inicia o poema já em movimento, já sugerindo o caráter infindável do ciclo escrita-leitura-vida.

Eis, porém, que, sem a materialidade - ainda que "instável" - do papel, essa experiência de retesamento do fluxo poético é perdida no desligamento da máquina, "tranco", "corte brusco de luz", ou ainda no navegar das diversas "janelas" abertas na tela, instaurando uma curiosa dialética que nasce a partir da computação: o poema ora "está" na tela, ora é coberto por outra janela aberta; ele "está" gravado na memória do equipamento, porém reduzido a um código binário, em latência. Enfim, o advento da informática traz diversas novas questões ao mundo da escrita, da linguagem, e por consequência, da poesia, expressas no poema e na entrevista de Armando Freitas Filho.

Se o computador enquanto suporte refletiu-se em determinadas produções poéticas, a popularização da internet já nos anos 2000 provocou mudanças definitivas no sistema editorial. Surgem blogs poéticos, narrativas hipertextuais, democratiza-se um pouco a publicação e o acesso à literatura, o que acarreta, também, um universo de obras sem filtros de editoras em uma pulverização de criações que dificulta o recorte crítico. Alguns escritores passam a usar redes sociais para divulgar seus poemas ${ }^{5}$, ou ao menos "testar" ideias e versos, verificando a reação dos leitores em poucos minutos. Essa dinâmica de escrita/leitura, perceptível no humor dos calembours de André Vallias lançados no Facebook 
e nos aforismos que Fabrício Carpinejar posta no Twitter, elimina qualquer mediação entre autor e público, e alimenta um novo tipo de fruição poética, de modo fugaz, passando em uma timeline em meio a tantos outros registros de linguagem. Concomitantemente, instaura-se um paradoxo: embora tais "micropoemas" estejam gravados no sistema do website - podendo ser acessados a qualquer momento -, eles acabam por desaparecer em meio à pletora de informações, notícias, mensagens pessoais, enfim, no fluir natural da interação dessas mídias de socialização. São, de certa forma, produtos estéticos momentâneos, talvez a mais fidedigna concretização do "poema-pílula" desejado por tantos poetas anteriores.

Ademais, a internet introjeta-se na poesia não apenas como veículo, mas também suscita inquietações de forma e conteúdo, como não podia ser diferente, já que ela vem revolucionando o cotidiano, com impactos sociais, econômicos e identitários. Sherry Turkle, no livro Alone Together, publicado mais de trinta anos depois de The Second Self, já citado anteriormente, afirma ter, no intervalo entre as obras, mudado significativamente sua definição acerca da informática:

Certa vez descrevi o computador como um "segundo self", um espelho da mente. Agora a metáfora não é mais suficiente. Nossos novos dispositivos fazem emergir um novo modelo de self, que se divide entre a tela e a realidade física, ambas conectadas por meio da tecnologia. (Turkle 2011: 26)

Mais adiante, a teórica afirma, ainda, que na era pós-conectividade, passou-se do "multitasking" ao "multi-lifing" (idem: 148), ou seja, a multiplicidade de tarefas e dimensões de atenção que as "janelas" nos exigiam foram convertidas em uma pluralidade de vidas simultâneas, performadas por perfis públicos, avatares, apelidos, "fakes" em ambientes de sociabilidade virtual. A contradição é explicitada no oximoro que nomeia seu livro, Alone together, síntese da solidão compartilhada que caracteriza o ser conectado. Um poema de Leila Míccolis ilustra bem esse sentimento:

\section{Domingueiras}

Do ciclo: Familiar

Aos domingos,

nosso amor acabado dói mais, 
talvez porque não haja novela

ou porque a conexão seja mais lenta

do que a usual,

com isto esvaziando as salas

de sexo virtual;

[...] (Míccolis 2013: 418)

Há claramente uma lógica entre a dor sofrida pelo fim de um relacionamento e o acesso à TV e à internet, tudo sob a ironia do título, que sugere atividades festivas. $\mathrm{O}$ enfado força o eu a pensar e a sentir, já que não está mais distraído pela hiperestimulação. Aos poucos, a substituição da interação corpórea e presencial pelo anonimato da Web, pelo conforto do isolamento ${ }^{6}$, pela virtualidade das relações. O mesmo tema está presente na canção "Nina”, de Chico Buarque (2011):

\section{$[\ldots]$}

Nina adora viajar, mas não se atreve

Num país distante como o meu

Nina diz que fez meu mapa

E no céu o meu destino rapta

O seu

Nina diz que se quiser eu posso ver na tela

A cidade, o bairro, a chaminé da casa dela

Posso imaginar por dentro a casa

A roupa que ela usa, as mechas, a tiara

Posso até adivinhar a cara que ela faz

Quando me escreve

Nina anseia por me conhecer em breve

Me levar para a noite de Moscou

Sempre que esta valsa toca

Fecho os olhos, bebo alguma vodca

E vou 
Há no álbum Chico, em diversos momentos, a percepção de um homem mais velho relacionando-se com o mundo contemporâneo e com mulheres mais jovens. Aqui, o relacionamento à distância, que evidentemente antecede a internet, ganha instrumentos de aproximação e realismo, como o uso de aplicativos como o Google Earth, que permite ver basicamente imagens do mundo todo. Mimetizando um zoom, a enumeração parte do mais geral para o mais específico (cidade/bairro/casa), enquanto a melodia acelera-se. No telhado, o limite da tecnologia, local de segurança da mulher que "não se atreve", característica geracional de quem já cresceu em um mundo conectado. Resta apenas a imaginação, o contato simulado entre avatares virtuais de indivíduos que passam a conviver primordialmente dessa forma. Uma observação importante que Turkle (2011) faz a respeito de redes sociais é que, como elas estão sempre lá, com seu rol de "amigos" disponíveis, perdeu-se o senso de escolha do momento de se comunicar, ou mesmo da necessidade de interagir. Está-se sempre em múltiplas conversas, grupos de troca de mensagens, em um acúmulo de interlocuções que extrapola qualquer tempo que se disponibilize para tal. Embora não se esteja sempre online, a representação latente do indivíduo está sempre lá, no "espaço" do chat, do site, do perfil. É o que a teórica chama de "performances do eu", supostas camadas de existência assumidas na vida digital que fragmentam nossa percepção espaço-temporal. Com isso, acaba-se sugado pela demanda gerada por tais interações:

Agora sabemos que, uma vez que os computadores nos ligaram uns aos outros, e já que nos tornamos acorrentados à rede, nós realmente não precisamos manter os computadores ocupados. Eles nos mantêm ocupados. É como se nós fossemos o principal aplicativo deles. [...] Falamos que "gastamos" horas no e-mail, mas nós, também, estamos sendo gastos". (Turkle 2011: 249)

É a prevalência de um novo tipo de comunicação, representada na canção de Chico Buarque pelo etéreo da imagem do destino e do céu, que contrasta ironicamente com a fisicalidade de "rapto". As relações tornam-se palavras trocadas, signos perdidos na vastidão da rede. O tema é retomado em seu álbum mais recente, Caravanas, a partir de uma nova versão de "Dueto" (Buarque 2017: faixa 6), originalmente lançada em 1980 em gravação com Nara Leão. A letra é muito conhecida: trata-se de uma jura de amor que cita diversos argumentos de autoridade que comprovam o destino promissor dos amantes, cuja felicidade 
"consta" em referências religiosas (evangelho; orixás; búzios), acadêmicas (tese; tratado) e legais (dados oficiais; autos; pauta) citadas em profusão enumerativa - a partir de um ritmo melódico que se tensiona com o correr da canção - que reforça a abundância dessas "provas" de sucesso daquela paixão.

Em seu relançamento 37 anos depois, Dueto tem como cantora ao lado de Chico Buarque a sua neta, Clara Buarque. Não há qualquer grande diferença rítmica ou poética entre as versões, exceto ao final da última, em que novos versos são adicionados: a relação passa a "constar" em websites e aplicativos como "Google", "Tinder" e "Facebook". Essa inserção não apenas ressalta o contraste geracional entre a jovem artista e o avô como gera certo desconforto no recobrimento da letra com a música, pois todas as palavras incorporadas são da língua inglesa, acarretando uma espécie de ruído, ficando nítida a artificialidade da presença delas naquela canção. Tal efeito desvela a estranheza com que o homem mais velho, anterior à geração millennial, encara esses novos "locais de autoridade" que substituem as antigas referências religiosas, acadêmicas e legais, e, principalmente, onde os relacionamentos se desenrolam.

Também na poesia publicada em livros há a exploração desse peso jurisdicional que determinadas funções da internet adquirem. Talvez o mecanismo de buscas Google seja o exemplo mais evidente de local virtual que encarna uma certa "voz da verdade", por ser de longe o website mais utilizado para a ordenação e organização do caos existente na internet. Basicamente tudo o que se quer encontrar será obtido por meio desse filtro, que ganha o poder de selecionar o que será visto ou não pelo usuário. Mais que isso, ganha status de complemento da memória humana, suporte automático de lembrança de dados que antes dependiam da memorização ou do registro em papel ou outro meio, talvez no mais perfeito caso de simbiose entre neurônios e algoritmos já estabelecida. Em poema recente, Eduardo Sterzi ironiza tal condição sem nomear a marca, mas em clara alusão ao Google:

\section{PERGUNTE AO ORÁCULO (MAIS UMA VEZ)}

Como fazer cupcake?

Como fazer chantilly?

Como fazer ganache?

Como fazer vermute? 
Como fazer costela?

Como fazer uma mulher

Da minha costela?

Como fazer sexo? (Sterzi 2016: 18)

A anáfora em "Como fazer" cria um paralelismo verticalizado que remete à função de "autocompletar" que o mecanismo de buscas oferece quando se começa a escrever em seu campo de texto. Segundo o suporte da empresa, "As previsões de pesquisa são geradas automaticamente por um algoritmo sem qualquer envolvimento humano. $\mathrm{O}$ algoritmo é baseado em vários fatores, como a frequência com que as outras pessoas pesquisaram um termo"7. Ou seja, as sugestões são, de certa forma, uma mostra do que os usuários mais pesquisam, tornando-se um substrato valioso para compreender as intenções dos internautas, o que está "em alta" nas procuras diárias. No poema em tela, o autor faz parecer que se trata de um objet trouvé, cuja autenticidade é irrelevante para a sua compreensão. A partir, então, da pergunta base "Como fazer?", surgem as alternativas de preenchimento, a priori prosaicas, até que a penúltima questão gera um estranhamento, que em combinação com a última, remete a Adão no livro bíblico do "Gênesis". Liga-se, então, a ideia ao "oráculo" presente no título, que pode tanto denotar tanto uma divindade consultada por um mortal como uma metáfora derrisória ao Google. Imagina-se, então, o primeiro dos homens verificando como fazer Eva, e como fazer sexo (depois da queda do Éden) no site de buscas, "mais uma vez", pontada chistosa que sugere uma substituição de Deus pelo algoritmo supremo que comanda a vida contemporânea, em clara crítica ao caráter corporativo que a rede mundial de computadores tem assumido.

Tal recurso poético recebeu o nome de "googlagem" por Ricardo Domeneck (2011) em texto que analisava poemas de Angélica Freitas, ligando a prática à poesia Flarf, tendência estética sobretudo americana que explora motores de pesquisa para compor textos que tendem ao nonsense. ${ }^{8}$ A poeta gaúcha talvez tenha sido a primeira no Brasil a ter proposto esse procedimento, em algumas peças de Um útero é do tamanho de um punho:

\footnotetext{
a mulher vai ao cinema

a mulher vai aprontar

a mulher vai ovular
} 


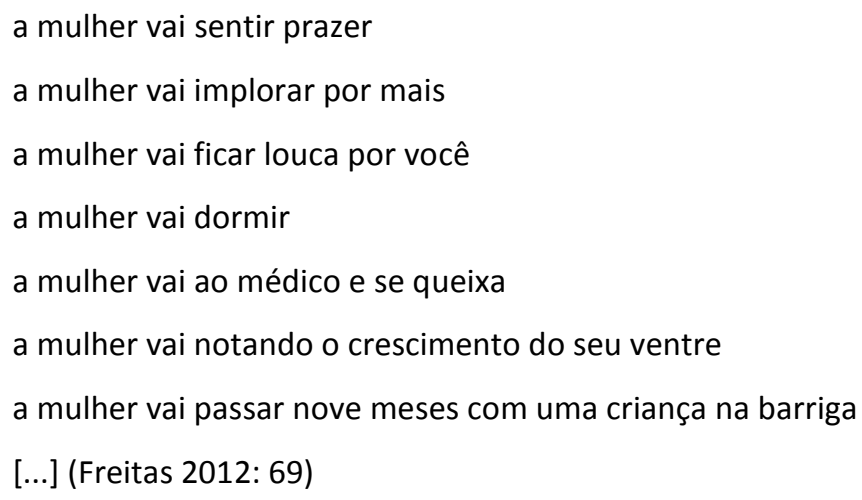

Da mesma forma, a anáfora remete às previsões de pesquisa, cujos resultados exibem as buscas mais comuns ligadas à mulher, em que se depreende todo o ideário relacionado ao feminino em um contexto machista: a maternidade, a satisfação sexual subjugada ao homem ("implorar por mais"; "louca por você"), enfim, escancara-se a mentalidade prevalente do usuário anônimo do Google.

Percebe-se que há, portanto, relevantes casos em que aspectos fundamentais da internet e desse cotidiano conectado se convertem não apenas tematicamente em crítica política na poesia, mas transformam sua estrutura, causando impactos estéticos claros. Outro exemplo em que o modus operandi do internauta é mimetizado poeticamente é “Índio (poema-wikipedia)", de Rodrigo Lobo Damasceno, publicado na antologia Vinagre (Os vândalos 2013: 145), cuja leitura simula o navegar no maior site enciclopédico do mundo. São listados, sem uma ordenação lógica ou coerente, eventos que ocorreram em 1964 (“Anita Malfati morreu em 1964"; "Em 1964 Martin Luther King recebeu o prêmio Nobel da \ Paz") enquanto trançam-se tempos verbais distintos ("1964 está sendo um ano \longo, escroto, árduo"; "Em 1964 Cassius Clay teve fé, \ se tornou Muhammad Ali \e derrubará índio e impávido - outro adversário: 1964") que projetam o ano do golpe militar no Brasil a um plano atemporal, tornando-se um "modo de ser" do país em seu passado e presente - o que fica mais claro quando se lembra que Vinagre agrega textos em resposta à violência policial vista na repressão das amplas manifestações de 2013. O último verso, porém, remete a um verso de Índio, canção de Caetano Veloso cujo horizonte utópico empresta ao poema de Damasceno uma esperança de ver o ano de 1964 - enquanto metáfora da truculência institucional brasileira - enfim vencido. 
O procedimento de simular o excesso de informações na rede e como elas são caoticamente recepcionadas pelo internauta, visto em “Índio (poema-wikipedia)", é recorrente em tentativas poéticas de se transpor o mundo virtual à poesia, reproduzindo-o em viés crítico. Em "A quimera" ${ }^{9}$, Italo Diblasi junta manchetes aleatórias de notícias que saltam aos olhos na frente da tela, unindo temas totalmente diferentes ("[...] gabigol revela motivo de não jogar \na europa. senado aprova texto de reforma $\backslash$ ministerial. daniel dias leva a décima \sexta medalha da carreira [...]"). Interessante notar com o enjambement quebra a sequência sintático-semântica das frases, desvirtuando o seu caráter fácil e chamativo, destruindo o seu poder de atração pelo click.

Já Marcos Siscar vai da enumeração de anúncios ao nonsense frente a uma caixa de entrada de e-mails:

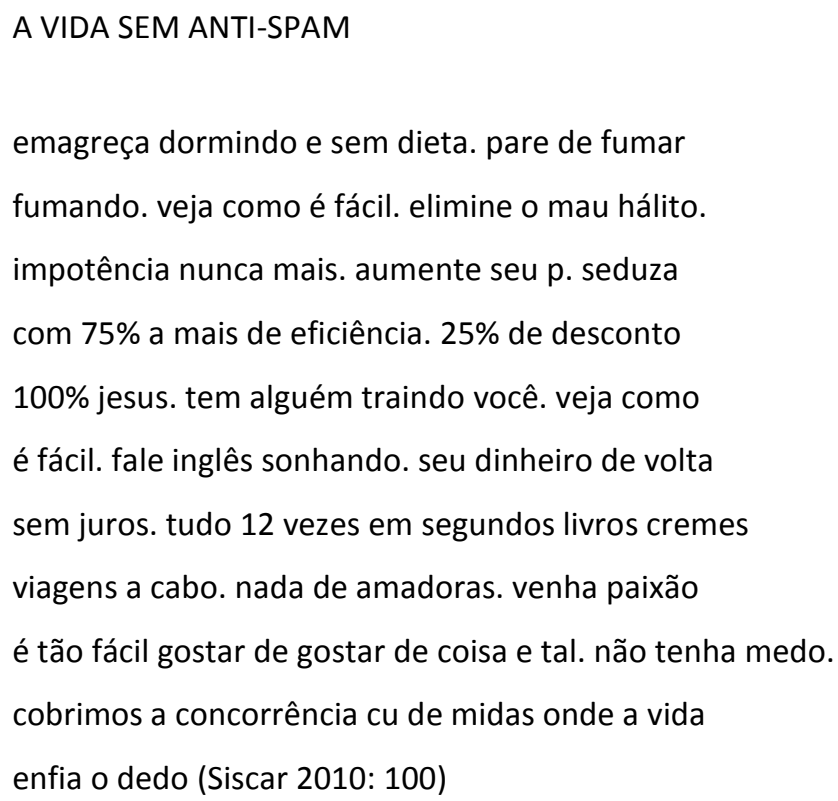

É como se os spams fossem sendo percorridos e apagados cada vez mais rapidamente, e seus verbos imperativos se impregnassem caoticamente na mente do usuário, obrigado a conviver com quantidades imensas do "lixo linguístico" que cruza a sua navegação, e do qual a propaganda representa significativa parte. Evidentemente, o furor do marketing não nasce a partir da Web, mas certamente se intensifica, o que polui a busca por dados específicos, força a perda de tempo e piora a hiperestimulação já inerente à rede. 
Do sétimo verso em diante, as frases passam a não fazer mais sentido, embora certos sintagmas ainda sejam reconhecíveis do discurso propagandístico. Nas últimas duas linhas, porém, há a inserção clara da voz do poeta, que interrompe o ready-made e propõe uma imagem, "cu de midas onde a vida \enfia o dedo", curiosa inversão do mito de Midas (cujo toque transforma tudo em ouro) em que "a vida", espécie de metonímia para "os outros", transforma em dinheiro o contato com aquele que recebe todas essas mensagens, obviamente prejudicado. ${ }^{10}$ Retratada, então, a posição de desigualdade entre anunciante e leitor, este constantemente seduzido por chamadas atraentes e muitas vezes falsas. O fecho "enfia o dedo" propõe uma duplicidade: "a vida enfia o dedo", lesando o destinatário; ou a leitura do verso isolado, simbolizando o clicar para o apagamento das mensagens, marca do tempo perdido e da overdose sensória que a internet representa, bem explicada por Turkle: Um e-mail ou mensagem de texto parece sempre estar rumo ao lixo. Hoje, como um fluxo contínuo de textos torna-se um modo de vida, podemos dizer menos coisas uns aos outros, porque imaginamos que tudo que dizemos é praticamente já descartável. Textos telegráficos, por natureza, certamente podem ser emotivos, inspiradores e sensuais. [...] Mas eles não servem para compreender de forma profunda um problema ou explicar uma situação complicada. Eles são momentâneos, eles preenchem lacunas de tempo. (Turkle 2011: 155)

Além da natureza impessoal, quando comparado ao telefone ou ao encontro presencial, o e-mail tem esse caráter fugaz e descartável que não se via na carta escrita. Além disso, ele tem uma complexidade muito maior na questão da privacidade, pois quando se envia uma mensagem eletrônica, não se tem certeza sobre quem tem acesso a ela, quem poderá lê-la, já que não há marcas de sua violação (em contraste ao envelope selado). É um modo de comunicação frágil e efêmero, mas que domina o intercâmbio de ideias no mundo, juntamente com os aplicativos de mensagens instantâneas, ainda mais fluidas e passageiras. O poeta Fabiano Calixto, em seu Nominata Morfina, tem um poema chamado "E-mail para Fabiano Calixto" (2014: 127), em que se reproduz exatamente a mensagem de devolução de um e-mail, recebida quando o contato não se efetiva. Repleta de linhas de comando em linguagem de programação - portanto, ilegível a quem não é técnico -, a mensagem não esclarece o motivo do problema no envio, deixando inerte aquele que tentou comunicar-se. 
Diversos dos poemas citados exploram o recurso do objet trouvé, que além de gerar reconhecimento no leitor acostumado ao mundo virtual, coloca em evidência as peculiaridades da rede. Em célebre texto sobre o ready-made de Marcel Duchamp, Octavio Paz afirma que o ato de retirar um objeto de seu universo cotidiano e levá-lo à cena artística provoca um duplo movimento de esvaziamento do sentido de existir da coisa apropriada, bem como de dissolução da noção de "obra de arte": "um dardo contra o que chamamos valioso" (Paz 2008: 31). ${ }^{11}$ Provocando, assim, uma "higiene do gosto", o procedimento renova as percepções de fruição e força o público a redefinir seu padrão estético, contrariando qualquer concessão ao "bom gosto", conceito paralisante abominado por Duchamp. Ao esgotar qualquer significado do que é exposto, resta somente sua forma, que no caso do objet trouvé reduz-se ao gesto político-artístico do autor, e a ironia que tal gesto carrega ao deslocar o estatuto do objeto à condição de arte. Mesmo essa intervenção autoral é mínima, momentânea, já que, uma vez tornada "arte", seu controle esvai-se. É quando, nesse desenlace, o artista descarrega criticamente a sua angústia:

\footnotetext{
Jogo dialético, o ready-made é também um exercício ascético, um caminho de purgação. Diferentemente das práticas místicas, sua finalidade não é a união com a divindade ou a contemplação da verdade: é um encontro com ninguém e seu objetivo é a não-contemplação. 0 ready-made se instala em uma zona nula do espírito. [...] Um niilismo que gira sobre si mesmo e se refuta: entronizar uma bugiganga e, uma vez ela estando em seu trono, negá-la e negar a si mesmo. Não um ato artístico: a invenção da arte de liberação interior. [...] É o que Duchamp chama a beleza da indiferença. Ou seja: liberdade. (idem: 38)
}

Nos Estados Unidos, alguns pesquisadores têm trabalhado o fenômeno percebido nos poemas citados. Brian Reed, por exemplo, atenta ao que ele chama de "linguagem redirecionada": "apropriar-se das palavras alheias, editá-las e apresentá-las como se fossem suas" (Reed 2011: 759), em um processo que converge, no limite, à impossibilidade de definição de autoria de qualquer discurso, uma vez que o entrecruzamento infinito de enunciados, em diversas mídias, na contemporaneidade, dilui a importância, ou mesmo a viabilidade, de uma "origem" criadora. O poeta, então, passa a ser um "word processor", termo que Marjorie Perloff (2011) usa para definir o ato de "absorver, recarregar e redistribuir a linguagem que já está lá". A expressão remete tanto a softwares de edição de 
texto, como o "Word", da Microsoft, quanto à sua acepção literal, "processador de palavras", sendo o escritor então aquele que organiza, delimita e dispõe as palavras já constantes no universo digital.

Veja-se, pois, um poema de Eduardo Sterzi ainda não publicado em livro, mas antecipado pela revista virtual Modo de Usar \& Co.:

\section{Unicórnios e chimpanzés}

É grande ofensa aos chimpanzés dizer que os ateus

[são seus descendentes?

Se o morto não é consciente quem fala nos centros

[kardecistas é o demônio?

Quem vai à igreja o faz por medo do inferno?

A existência de um umbral é prova de que a reencarnação é falha?

Quais as principais diferenças entre as nossas senhoras do bom parto

[e do mau parto?

Você tem saudade de alguém que já não está mais aqui?

O que a bíblia fala sobre hermafroditas?

Que animal não coube na arca de noé?

Tristeza atrai satanás?

Por que os atuais chimpanzés estão em greve de evolução

e não querem se tornar humanos?

Unicórnios têm algum significado maligno?

O amor é uma ilusão?

Qual é a música mais triste do mundo?

E se deus não existir?

Quando alguém morre é por vontade de deus?

Dá para ser cristão acreditando apenas em algumas partes da bíblia?

Jesus foi paranormal ou escritor?

Quando estou sonhando não sei que estou sonhando

como posso saber se este exato momento é real? 
Se o sol morrer ressuscita?

Não foi a princesa isabel que libertou os escravos mas sim jesus?

E se quando você morrer descobrir que nada na bíblia é real?

Enterrar pessoas junto com foto faz mal?

Se a terra é um planeta expiatório nunca teremos um mundo melhor?

Estou no caminho certo?

É verdade que deus canta? (Sterzi 2014)

Tem-se, aqui, um equivalente literário da assemblagem, espécie de mosaico de alguns ready-mades. Em diálogo óbvio com o supracitado "Pergunte ao oráculo (mais uma vez)", apresenta mais uma coleção de questões, porém não mimetizando o Google, já que não há anáfora. O leitor parece passear por um site de perguntas e respostas, como o Quora ou o Yahoo Respostas. Chama a atenção a repetição da temática do outro poema, a questão religiosa, dessa vez confrontada com menções ao Evolucionismo.

Retiradas, pois, de seu contexto, e sem o complemento de suas réplicas, as indagações - já cômicas de tão insólitas - esvaziam-se, montando uma miscelânea de carcaças linguísticas despejadas em um ato literário que se reduz ao gesto dessa compilação. A ironia reside em trazer à poesia - local de expansão dos horizontes da língua, de reflexão da linguagem torcida sobre si mesma - amostras radicais da completa banalização da palavra que se deflagra na rede, não apenas uma "floresta de signos", mas uma "floresta de simulacros", universo infinito de manifestações verbais e imagéticas que, por um lado, cumpre o seu potencial de comunicação e informação, mas que, por outro, gera um macrocosmo insano de dados que sabota esses mesmos papéis.

Se os recursos do ready-made e da assemblagem mostram-se recorrentes em obras poéticas que repercutem a Web, é porque seus autores sentiram-se compelidos ao gesto que escancara o vazio do mundo virtual e, ao mesmo tempo, os liberta dele. É uma estratégia artística possível, entre outras que merecem estudo à parte, como certa produção que vem incorporando a ideia de avatar e de performance de si ao resgatar e intensificar representações de fragmentação e dissolução egoica (fenômenos discutidos anteriormente à internet, mas que ganham novos elementos a partir dela). Penso em poemas como 
"Personagem", de Eduardo Sterzi (2009: 57), modulação serialista de eus a partir da mínima variação da ortografia do sobrenome do poeta (Eduardo Stenzi; Eduardo Strezi; Eduardo Sperb, etc); ou nas autobiografias de Fabiano Calixto (2014: passim), coleção de quatro poemas chamados "Autobiografia" espalhados pelo Nominata morfina, cada um trazendo uma narrativa diferenciada, como "autoficções poéticas".

No que ao tange ao escopo desse artigo, porém, creio ter ficado claro que a apropriação do objet trouvé virtual - "internet trouvé" - responde a uma urgência de expor a natureza fútil, às vezes absurda, às vezes opressora da massa de discursos, afetos, projeções e performances identitárias que compõem uma espécie de "esfera pública", conceito que Habermas (2014 [1962]) cunhou pensando na constituição, a partir da sociedade burguesa, do ideário de uma coletividade de pessoas privadas, uma dimensão discursiva comum em que coabitam indivíduos e subgrupos absolutamente multiformes, diferentes entre si. Ao tirar excertos dessa esfera e isolá-los no tablado do poema, os autores citados explicitam a banalidade que dela verte e iluminam os efeitos da conectividade, do anonimato e da excessiva exposição sígnica sobre a linguagem, as mídias e a sociedade como um todo. Esse gesto, conceitual e incisivo, ressignifica o conteúdo apropriado e o transforma em pièce de résistance do universo em que foi retirado, parte que metonimicamente expõe a frivolidade dos meios digitais. Tal prática, então, resulta um caráter político ao subverter a língua contra si mesma, em torção autófaga, deflagrando, a partir da particularidade dos exemplos pinçados, as idiossincrasias coletivas da Web, a saber, o seu falseamento informacional, a sua potência difusora de discursos dominantes e perpeturadora de enunciados excludentes, anomalias essas que, no poema composto a partir do procedimento "internet trouvé", aclaram-se imediatamente ao leitor. 


\section{NOTAS}

1 Ambos os textos citados de Mallarmé foram traduzidos ao português por Amálio Pinheiro na coleção Fundadores da Modernidade (Mallarmé 1991).

${ }^{2}$ As citações às obras de Turkle foram traduzidas livremente por mim.

3 Turkle (2005: 159) chega a citar a oposição ferramenta/máquina que Marx propõe no décimo-terceiro capítulo de seu O Capital, sendo a primeira uma extensão do usuário e, a segunda, um dispositivo que obriga seu operador a funcionar conforme o seu ritmo mecânico. A aplicação desses conceitos para o computador, porém, soa insuficiente, já que, na explicação do filósofo alemão, a ferramenta servia a trabalhos como o de artesãos e ferreiros, ao passo que a máquina abrangia qualquer mecanismo que escape ao controle do trabalhador. A informática parece trazer aparatos de outra ordem, com sua autonomia funcional, sua operação multidimensional em que várias coisas acontecem em concomitância e sua arquitetura virtual (software) totalmente desconhecida daquele que a usa.

${ }^{4}$ Para uma abordagem extensiva - e crítica - de tais teorias, ver Santaella 2007.

${ }^{5}$ Um exemplo claro da relevância da Web como plataforma de publicação é o livro $A$ extração dos dias, organizado por Gustavo Silveira Ribeiro (2017), disponível apenas online em sua forma digital, contendo poemas de diversos poetas contemporâneos de alta relevância. Chama a atenção, ainda, que dois desses poemas sejam links para o Youtube, onde se veem performances poéticas de Érica Zíngano.

6 “Preenchemos nossos dias com a conexão contínua, nos negando tempo para pensar e sonhar. Ocupados até a exaustão, fazemos uma nova barganha Faustiana, que ocorre assim: desde que estejamos sozinhos para entrar em contato, suportamos a convivência" (Turkle 2011: 184-5).

${ }^{7}$ Trecho extraído do suporte do Google, disponível em < https://goo.gl/6HufKs >, acesso em 13 de abril de 2018.

${ }^{8}$ É importante ressaltar que os poetas adeptos da Flarf Poetry costumam recortar e colar os resultados das buscas a partir de termos-chave aleatórios, diferentemente do que fizeram Eduardo Sterzi e Angélica Freitas nos exemplos aqui exibidos, já que eles se ativeram ao (ou simularam o) recurso do "autocompletar" do campo de busca. Para uma análise mais detida da Flarf, cf. Bernes, 2016; para uma notável coleção de poemas em inglês a partir do Google, cf. o blog "Google Poetics", disponível em < https://goo.gl/EiuHXR>, acesso em 10 de julho de 2018.

${ }^{9}$ Disponível em < https://goo.gl/x4jU1v>, acesso em 14 de abril de 2018.

${ }^{10}$ Vale lembrar que, segundo o mito grego, depois de obter o toque de ouro, Midas ainda receberia "orelhas de burro".

${ }^{11}$ As citações a Paz são uma tradução livre a partir do original, feita por mim. 


\section{Bibliografia}

Agamben, Giorgio (2002), “O fim do poema”, Cacto, São Paulo, n. 1, 142-149, [1995].

Bernes, Jasper (2016), “Art, Work, Endlessness: Flarf and Conceptual Poetry among the Trolls", Critical Inquiry, n. 42, The University of Chicago, $760-782$.

Buarque, Chico (compositor e intérprete) (2017), Dueto, faixa 6, Rio de Janeiro, Biscoito Fino.

-- (compositor e intérprete) (2011), Nina, faixa 8, Rio de Janeiro: Biscoito Fino.

Calixto, Fabiano (2014), Nominata Morfina - Livro de gravuras, São Paulo: Corsário Satã; São Paulo: Editora Córrego; São Luís do Maranhão, Pitomba Livros e Discos.

Domeneck, Ricardo (2011), Alguns poemas memoráveis da última década: "sereia a sério", de Angélica Freitas, disponível em < https://goo.gl/kMjbir>, acesso em 14 de abril de 2018.

Freitas, Angélica (2012), Um útero é do tamanho de um punho, São Paulo, Cosac Naify.

Freitas Filho, Armando (2000), "Armando Freitas Filho: entrevista”, entrevista a Adolfo Navas Monteiro, in Cult, n. 40, nov. 2000, 4-11.

-- (2003), Máquina de escrever: poesia reunida e revista, Rio de Janeiro: Nova Fronteira.

Gil, Gilberto (compositor e intérprete) (1969), Cérebro Eletrônico, faixa 1, lado A, Rio de Janeiro, Phillips.

Habermas, Jürgen (2014), Mudança estrutural da esfera pública: investigações sobre uma categoria da sociedade burguesa, São Paulo, Ed. Unesp [1962].

Mallarmé, Stephane (1991), "O livro, instrumento espiritual" e "O mistério nas letras", tradução de Amálio Pinheiro, in Chiampi, Irlemar (coord.), Fundadores da modernidade, São Paulo, Ática, 125 - 132.

Míccolis, Leila (2013), Desfamiliares: obra completa de Leila Míccolis 1965-2012, São Paulo: Annablume. 
Os Vândalos (2013), Vinagre: uma antologia de poetas neobarrocos, São Paulo: Edições V de Vândalo, e-book.

Paes, José Paulo (2008), Poesia Completa, São Paulo: Companhia das Letras.

Paz, Octavio (2008), Apariencia desnuda: La obra de Marcel Duchamp, 5.ed., Madri: Alianza Editorial [1973].

Perloff, Marjorie (2011), Towards a conceptual lyric: From content to context. Disponível em <https://goo.gl/AgBFUw>, acesso em 10 de julho de 2018.

Reed, Brian (2011), In Other Words: Postmillennial Poetry and Redirected Language, Contemporary Literature, vol. 52, n. 4, pp. 756-790, Madison, Wiconsin University Press.

Ribeiro, Gustavo S. (org.) (2017), A extração dos dias [poesia brasileira agora], Curitiba: Revista Escamandro, e-book. Disponível em <https://goo.gl/245rRx>, acesso em 15 de abril de 2018.

Santaella, Lucia (2007), "Pós-humano - por quê?", Revista USP, São Paulo, n.74, p. 126-137.

Siscar, Marcos (2010), Interior via satélite, São Paulo, Ateliê Editorial.

Sterzi, Eduardo (2009), Aleijão, Rio de Janeiro, 7Letras.

-- (2016), Maus poemas, Rio de Janeiro, Megamini/7Letras.

-- (2014), "Unicórnios e chimpanzés", in: Modo de Usar \& Co., disponível em <https://goo.gl/vEJwfP>, acesso em 14 de abril de 2018.

Turkle, Sherry (2011), Alone together: why we expect more from technology and less from each other, New York, Basic Books.

-- (2005), The second self: computers and the human spirit, Cambridge (MA), MIT Press [1984]. 
Sérgio Bento é professor adjunto da Universidade Federal de Uberlândia. Doutor em Teoria Literária e Literatura Comparada pela Universidade de São Paulo, possui capítulos de livro e artigos sobre poesia moderna e contemporânea e tradução literária, abrangendo temas como as obras de José Paulo Paes, Ferreira Gullar, Carlos de Oliveira, entre outros; as relações entre humor e poesia; e os conceitos de transcriação. Coordena o GEPOC, Grupo de Estudos de Poesia Contemporânea. 